\title{
Frihedens ulidelige lethed
}

\section{en kommentar til Henrik Bjelkes „Time out"}

\section{DORTHE JØRGENSEN}

Det var efterår, og hun forlod festen med frakken skødesløst fejende omkring sig i vinden. Det var mørkt, og det var nat, og hun gik igennem et udkantsområde af byen, men hun var ikke bange. Hun ikke gik, men fløj, ikke igennem byen, men tilværelsen. Hun lagde samtalen med venner og musikken og dansen, mænd, som havde onsket, at hun blev lidt længere og sin egen flirt med dem bag sig. Hun vandrede i frihed, uforpligtet og svævende let. En lille megaloman succesfuld ballon midt $i$ nattens mørke. Da hun kom hjem, gik hun straks i seng. Der var tomt.

Henrik Bjelkes novelle rummer et problem, ikke blot fænomenologisk, men også i sin måde at gå til det. Problemet er, at den fænomenologiske registrering, som den udtrykker, er fremragende sensitiv og flot gestaltet litterært, men at den „løsning" på problemet, som den udsiger, er lige så problematisk som problemet selv. Havets evige uforanderlighed som metafysisk forankringspunkt i en tilværelsesopfattelse præget af et monomant behov for at undslippe enhver form for social forankring. Sådan var også mørket for hende, da hun fri af alt og alle vandrede hjem.

Det moderne menneskes drømmeunivers er præget af en dobbelthed af længsel efter at undslippe faste former i betydningen forpligtende krav og at søge et højere holdepunkt hinsides midt i den selvskabte tomhed. Det er romantisk idealisme, udtrykt så smukt i romantikken i form af den digteriske sværmen for "die ferne Geliebte“. Man ønsker, men vil ikke have. Man vil, og man vilikke. Man ved egentlig ikke, hvad man vil, men tydeligvis vil 
man dog noget. Abstrakt. Bliver det konkret, bliver det uudholdeligt - auraen forsvinder.

Det ligger imellem linjerne i Bjelkes novelle. Hvilken salighed at lægge hverdagens krav og andre mennesker bag sig for en uge, at abstrahere fra tiden og bare være til i nu'et. Men hvilken primitiv tomhed tillige. Vi regredierer til en sfære, hvor rytmen er bestemt af peristaltikken og solens vandring i horisonten, og det hele gentager sig i slet uendelighed fra dag til dag. Denne trækken sig ind i sig selv og bort fra omverdenen gør det pludselig meget interessant, hvilke vædsker eller konsistenser, som flyder fra eens krop. Vi ser det $i$ de seneste års litteratur. Og i denne „kropslighed" finder man i sit eget lille univers en fællesnævner med den samlede menneskehed. „Vi er alle lige, for vi alle indoptager og udsondrer". Mere interessant ville det dog vel være, om vi også var lige - og lige forskellige - $\mathrm{i}$ ånden.

I Bjelkes novelle taler en søgen efter "Gud", som omsættes i en total afskrælning af enhver form for social konkretisme. "Jeg er mig, hvis ingen ser mig, og jeg ser ingen." "Jeg er identisk med mig selv, når jeg fordyber mig i det evigt selvsamme hav." Og det er løgn. Det er en salig rus at „være ude af sig selv", men man får ikke sig selv tilbageigen, hvis ikke dette „ude”, som man er „ude af sig selv"i,rummer meresubstans end et evigt samme hav eller mørke. En modstand er en uomgængelig nødvendighed: oplevelsen af en anden konkret persons personlighed eller af konkrete faglige krav til een selv, som bliver stillet med forventning om at blive opfyldt. Hegel havde fat i det: at vi ikke bliver os selv igennem abstraktion fra alt udenfor os, men igennem engagement i det omkring os.

Da hun stod op næste dag, var det uden nødvendighed. Ingen og intet kaldte, det stod hende frit for at vælge imellem intet at gøre eller at tage sig noget til. Hun kunne tage bad, eller hun kunne lade være. Hun kunne læse avisen 'eller lade den ligge. Hun kunne gå på arbejde eller ikke, da hun selv var herre over, hvornår og hvor og i hvilket omfang hun skulle præstere noget. Der hvilede intet andet blik på hende end hendes eget, og det så, hvad hun egenrådigt valgte at se eller at lade ude af syne. Hun var fri - til at være ingenting. 
Af Sartre lærer vi, at de andres blikke er en forbandelse. De leverer fortolkninger af os, som vi aldrig kan identificere os helt med. De fælder domme, hvis grundlag vi finder uholdbart, og hvis vurderinger er os uacceptable. "Se MIG, som jeg er", signalerer vi alle, alt mens vi overvældes af "billeder" af hinanden, som aldrig forekommer at stemme med den virkelighed, som vi selv mener at være for os selv. Da vælger modernisten at betragte socialiteten som en pest, at ophøje kontingensen og melankolsk at dyrke ensomheden. „Berør mig ikke med dit blik“, lyder kravet. „Angrib ikke min suverænitet." Uerkendt forbliver det, at denne angst beror på en identitet så skrøbelig, at den end ikke kan tåle at blive betragtet af en anden. Og stærkere bliver den ikke af at flygte fra konfrontationen.

Personen i Bjelkes novelle finder lyksalighed i at undslippe det sociale fællesskab, arbejdets krav, den temporale orden, de andres blikke. Friheden søger han i sublim sammensmeltning med det evigt samme hav. Vi har set det før. Romantikerne begav sig ud på samme rejse i den absolutte idealisering af den elskede. For de tidlige ekspressionister udgjorde 1. verdenskrig muligheden for en totaloplevelse. Anti-totalitære og fascister er århundredet igennem mødtes $i$ en fælles længsel efter suggestiv ophævelse af forskellen - imellem krop og sjæl, dig og mig, jeg og mig selv.

Men da hun skænkede kaffen, som hun havde lavet, skønt hun kunne have ventet eller helt have undladt at brygge den, var det med en fornemmelse af, at der var en anden til stede. Hun kan umuligt være den, som han tror, at hun er, men $i$ sine gesti følger hun spontant de konturer, som han tegner sit rids af hende med. Hun bliver sig af det blik, som imaginært hviler på hende. Hans fiktive nærvær gør hende til den, som hun kunne være. Deri ligger der ingen forbandelse.

Feminismen har misforstået det maskuline blik. Det antages at være objektiverende, manipulatorisk, magtbegærligt. Ingen har formuleret den tanke, at det kunne være kærtegnende. $\mathrm{Og}$ dog, mænd selv har, f.eks. Walter Benjamin: „Den, der elsker, hænger ikke kun ved den elskedes "fejl“, ikke kun ved en kvindes særheder og svagheder, han er meget mere varigt og ubønhørligt bundet af ansigtsrynker og leverpletter, slidte klæder og 
en skæv gang, end af al skønhed. Det har man forlængst erfaret. Og hvorfor? Hvis den lære er sand, som siger, at det at opfatte ikke finder sted i hjernen, at vi ikke opfatter et vindue, en sky, et træ i hjernen, men på det sted, hvor vi ser dem, så er vi i vort blik på den elskede ude af os selv. Her imidlertid pinefuldt anspændte og henrevne. Blændet flagrer fornemmelsen som en fuglesværm i kvindens glans. Og ligesom fuglene søger ly i træets løvrige skjul, således flygter fornemmelserne ind i den elskede krops skyggefulde rynker, uskønne gesti, og uanselige pletter, hvor de kryber sikkert i skjul. Og ingen forbipasserende gætter, at netop her, i det mangelfulde, dadelværdige, har tilbederens lynsnare kærlighedsfølelse hjemme." (Ensrettet gade, p. 8, Modtryk 1993.)

Ikke blot kærligheden var det Benjamin beskåret at have bedre blik for, end Sartre havde, men også human (i ordets egentlige betydning) adfærd i det hele taget. Oplevelsen af den andens blik som en forbandelse er manifestationen af en neurotisk nærhedsangst, hvis mere sociale og kommunikative søster i neurosernes register er den hysteriske fornøjelse ved at være i fokus af et blik. Den, der ikke vil ses, vil heller ikke give - tilstedeværen, nærhed, kommunikation. Den nærhedsangste er en social "fedterøv", der puger sammen af resterne af det "jeg", som han aldrig har etableret, som om det drejede sig om at lægge i banken til pensionsalderen. Personen i Bjelkes novelle er socialt forskræmt - og sikkert ikke "fedtet" kun i ferien.

Da hun slukkede for radioen og tog hul på dagens forpligtende uforpligtethed, strejfede mindet hende. Om den aften, hoor hun som en imaginær gudinde fantasmatisk vandrede igennem det tomme rum. Om dage spundet $i$ og af forestilling alene. Om insisteringen på det absolutte fravær af blik udefra. Den totale abstraktion fandtes dog aldrig virkelig. Var ikke han der, var der fantasien, altid en målestok af en slags. Intet oplevet, intet følt og gjort og tænkt uden under auspicierne af et blik af en slags et eller andet sted i verden, om så "inde" eller "ude", om så en konkret andens eller som en fiktion. Netop $i$ den mest villede uforpligtethed, $i$ den højeste grad af "frihed", blev udtænkt de størst tænkelige krav - som værn mod frihedens ulidelige lethed. 
Aner nogen lykke i den abstrakte frihed, som personen i Bjelkes novelle søger i sin selvskabte isolation? Er det tilfældigt, at personen er unavngivet, han som fremtræder identitetsløs, kendetegnet ved i sin flugt fra den sociale orden at blive en fiktion for sig selv? Aner vi ikke desperationen i den længsel efter ro, som kun kan finde tilfredsstillelse i betragtning af det evigt samme hav? Det kunne have været anderledes. Han kunne have fundet den søgte erfaring af "helhed" $i$ intens samtale, i venskab og reel kommunikation med andre, i formålsløst formålsmæssigt arbejde båret af lyst, $\mathrm{i}$ hengiven erotik krop mod krop hinsides nogen anden orden. I en nydelsesfyldt omgang med det, som er, eller som kan skabes sammen med andre, i direkte eller formidlet gensidigt nærvær. Hvis han havde været en anden.

Den problematiske løsning på det rejste problem i Bjelkes novelle er derfor ikke mere problematisk end, at novellen på genuin modernistisk manér følger den model, som Th. W. Adorno kaldte "negativt dialektisk". Billedet bliver tegnet så sort i sort, så håbløst ueftertragtelsesværdigt, at et modbillede uvilkårligt dannes i læserens bevidsthed. „Nej, sådan ønsker vi det ikke.", svarer vi umiddelbart. „Den anden er ikke min forbandelse, men min mulighed." "Havet kan jeg pseudo-suicidalt kontemplativt lade mig opløse i, men jeg begærer ikke at forsvinde." "Jeg kender den abstrakte fornøjelse ved at sætte mig ud over alt og alle, at lægge mine roller bag mig og abstrahere fra tiden. Men resultatet er kedsommelig tomhed." Reformistisk nytolkende borgerligheden springer en etik frem med mottoet „Forpligtethed adler". Ikke bundethed af hvad og hvem som helst, men storheden ved at vælge at engagere sig, skønt man kunne lade være. Det var måske, hvad Fr. Nietzsche forstod, selvom han formulerede sin indsigt på måder, som er åbne for forskellige udlægninger.

Netop Nietzsche mindes hun, da hun om aftenen slukker lampen, ikke efter en fejende march fra alt ind $i$ intet, men efter samtale. Hun oversatte tidligere Nietzsches filosofi til det primitive ordsprog, som hævder, at "intet er så skidt, at det ikke er godt for noget". Det forekom ikke at gøre vold på Nietzsche og slet ikke på muligheden for at kunne udholde og få noget konstruktivt ud af -f.eks. "de andres blikke". Det 
slår hende, at Hegel for så vidt var nietzscheaner eller Nietzsche hegelianer. Hegel insisterede på friheden, men ikke den abstrakte. Nietzsche anfægtede den normative bundethed, men krævede satsning på forpligtende engagement. På grænsen til søivnen erkender hun, at de to var enige om een ting mindst: at nære respekt for viljen. Hvor der er vilje, er der håb, og hvor viljeskraften forvaltes med omhu, er selv det, som rækker ud over det givne, muligvis ikke umuligt. Måske sågar balance imellem nødvendig frihed og ulidelig lethed. Da hun vågner, er hun ikke alene. Og dog er hun fri. 